\title{
Poisoning Associated with Ingestion of Redroot Pigweed (Amaranthus ret- roflexus) in Cattle - Case Report
}

\author{
T. Zadnik ${ }^{1}$, J. Starič ${ }^{1}$, M. Klinkon ${ }^{1}$, T. Cigler ${ }^{2}$ and J. Ježek ${ }^{*}, 1$ \\ ${ }^{I}$ University of Ljubljana, Veterinary Faculty, Clinic for Ruminants, Cesta v Mestni log 47, 1000 Ljubljana, Slovenia \\ ${ }^{2}$ Veterinary Polyclinic Brestanica, Šolska 15, 8280 Brestanica, Slovenia
}

\begin{abstract}
On a farm in Slovenia two cows died overnight without any previous signs of disease. The cows were fed green forage, containing a big portion of redroot pigweed (Amaranthus retroflexus) at least for four consecutive days. Poisoning with this plant was suspected. Pathomorphological changes established by the necropsy of both cows confirmed the suspicion of poisoning.
\end{abstract}

Keywords: Cows, Amaranthus retroflexus, redroot pigweed, poisoning, sudden death.

\section{INTRODUCTION}

Redroot pigweed (Amaranthus retroflexus) is a one year plant, which grows $30-130 \mathrm{~cm}$ in height. The plant is a common weed often found on the fields, it prefers dry soil [1]. Redroot pigweed is a common plant worldwide including Slovenia. Poisoning of cattle with this plant was reported already in 1963 [2], since then only a few reports have been published on this topic [3-7]. Poisoning of cattle in Slovenia has not been reported yet [8]. Usually the poisoning takes place on the pasture mostly during the times of drought when appropriate forage is unavailable and cattle may ingest toxic amounts of redroot pigweed. Poisoning with redroot pigweed has been reported including in pigs. Apparently, pigs like to eat this plant $[9,10]$. Poisoning with redroot pigweed causes injury of kidney and perirenal oedema in cattle and pigs [3, $5,10,11]$ but not in rabbits [12]. The plant is toxic because of the ability to accumulate high amounts of nitrates in the stems, especially if it is growing on the soil rich with nitrogen. The leaves contain an incomplete defined toxin which causes nephrotoxicosis. The plant also contains soluble oxalate $[5,10,13,14]$ (Fig. 1).

\section{CASE REPORT}

The first week in July 2007 a local veterinarian who is working in the south east region of Slovenia came to the Clinic for Ruminants. He reported that the only two cows on the farm suddenly died during the night. The cows were of Simmental breed, 4 and 10 years old, approximately $500 \mathrm{~kg}$ of body weight. The owner did not notice any previous signs of disease. On the floor around the dead cows no signs of restlessness were found, bedding was not scattered, indicating that the animals died without agony or excitations. The cows were fed twice a day with green forage from the field where clover was sown. The veterinarian did not find clover in the crib, but only some unknown green plant, was also found when he checked the forage stored in front of the cowshed. The owner told him the cows were eating this forage

*Address correspondence to this author at the University of Ljubljana, Veterinary Faculty, Clinic for Ruminants, Cesta v Mestni log 47, 1000 Ljubljana, Slovenia; E-mail: Jozica.Jezek@vf.uni-lj.si

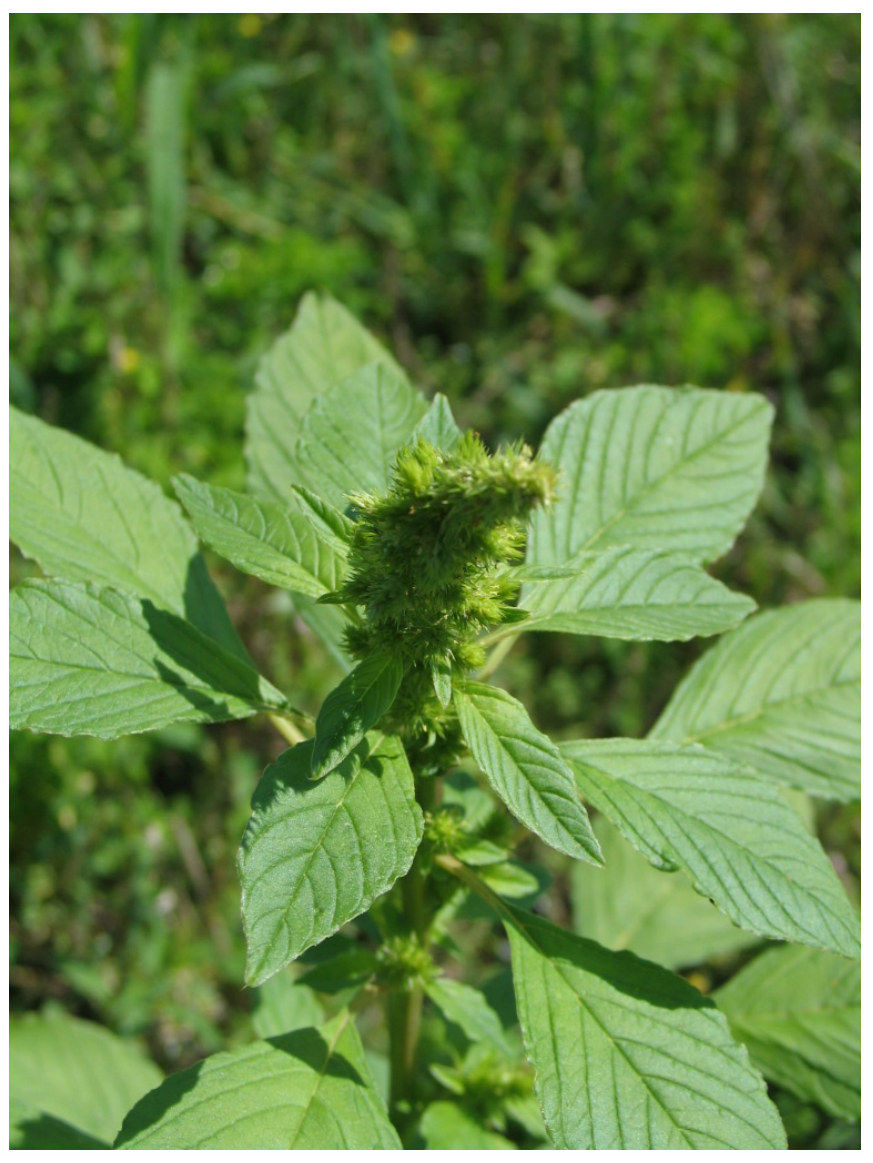

Fig. (1). Redroot pigweed (Amaranthus retroflexus) (Foto: M. Klinkon).

for at least four days. On the base of anamneses and his own findings the veterinarian suspected the poisoning and he sent both cows to post mortem examination. The suspicious plant was brought to the Clinic for Ruminants, where we established that the plant is a redroot pigweed (Amaranthus retroflexus); our establishment was confirmed by the expert in the botanical garden Jože Bavcon, PhD (personal communication). 
Pathomorphological examination in both cows established hemorrhagic subcutaneous oedema on the abdomen and moderate rumen tympany. In fore stomachs green fibrous contents were found and in one of the cows ruminitis and obstipation of omasum were ascertained. The intestine of both cows was filled with gas. In both cows hyperaemia and oedema of lungs as dilatation of heart were established. In pericardium $2-3 \mathrm{dl}$ of clear yellowish red fluid was found. The kidneys were swollen with perirenal oedema. Histopathology of kidney was not performed. The results of post mortem examination confirmed the suspicion of poisoning. The veterinarians from the Clinic for Ruminants visited the farm after this incident and took the precise anamnesis again. We established that the forage which was provided to the cows contained at least $80 \%$ of redroot pigweed. The cows were getting smaller amounts (approximately $10 \mathrm{~kg}$ per meal) of this forage but when the owner saw they liked to eat it she gave them more, and at least $20 \mathrm{~kg}$ were fed in the evening, prior to death the next morning.

\section{DISCUSSION}

Before sudden death the cows in this case were fed with green forage which contained a big portion of redroot pigweed for at least four days. In that period there was enough moisture so the plants were growing fast and the redroot pigweed overgrew the field sown with clover. It is known that redroot pigweed is a strong competitor and can supplant other plants [1]. The time from exposure to the poisoning of cows was similar to the other reports $[3,5]$. The cows in this case died suddenly without any clinical signs of disease. The Spearman [4] also reported that the cattle were found dead on the pasture. Other authors reported about clinical signs like posterior incoordination, weakness, trembling of the muscles of the hind limbs, depression, diarrhoea and extensive ventral subcutaneous oedema. The death followed in $1-$ 14 days after onset of clinical signs. In the blood samples of affected animals increased concentrations of urea, creatinine and activity of CPK (creatine phosphokinase) were established [3, 5-7]. Similar clinical signs were reported in poisoned pigs [9] and in poisoned cattle with Amaranthus hybridus in South Africa [15]. The redroot pigweed is able to accumulate a high level of nitrate and can be toxic to the kidneys especially when grazed fresh on the field [16]. Clinical signs described in nitrate poisoning are different from the signs established by redroot pigweed poisoning. In nitrate poisoning the nitrate is reduced to nitrite in the rumen. Nitrite converts haemoglobin to methaemoglobin, causing the brown discoloration of mucus membranes and blood. In acute cases clinical signs appear $2-6$ hours after intake of food containing high level of nitrate. Signs include polypnoea, dyspnoea, tachycardia, abdominal pain, tympany, diarrhoea and frequent urinating. Muscle tremor, weakness, intolerance to exercise, convulsions, and death is possible in just few hours $[17,18]$. The cows in our case died without convulsions, what was established also in the report by Sperman (1989) [4]; this is not typical for poisoning with nitrate.

Gross pathomorphological examination of both cows established haemorrhagic subcutaneous oedema in abdominal region, perirenal oedema and fluid in pericardium in our case. The established pathomorphological changes agree with findings of other authors. In cows that died due to redroot pigweed poisoning they found increased quantity of fluid in body cavities, subcutaneous oedemas and petechial haemorrhages on serous surfaces. Perirenal oedema, swollen kidneys with petechial haemorrhages were also established, histopathological necrosis of tubules was ascertained [3, 5-7, 11], and similar changes were established also in pigs [9]. Pathomorphological changes in poisoning with redroot pigweed are different from changes appearing in poisoning with nitrate. Changes in nitrate poisoning include brown coloured blood and tissues, cardiac haemorrhage, poor clotting of blood and pulmonary congestion. Frequently, overload of forestomachs, hyperaemia of mucosal membranes of alimentary tract, hyperaemia of lungs sometimes with interstitial emphysema, and fluid in pericardium are found [16-18].

On the basis of case history; the cows were fed by forage containing a lot of redroot pigweed for at least 4 days, the evening prior to death they got a bigger quantity (at least 20 $\mathrm{kg}$ ) of this forage. Due to the results of postmortem examination which agreed with findings of other authors we are of the opinion that the cows died because of poisoning with redroot pigweed.

\section{CONCLUSIONS}

This is the first case of poisoning of cattle with Amaranthus retroflexus reported in Slovenia. Poisoning with this plant is probably caused by the combination of unknown nephrotoxic agent, nitrate and oxalate. Different species of Amaranthus are used as ornamental or forage plants but Amaranthus retroflexus is a common weed also in Slovenia, and due to lack of knowledge in people it is possible that more cases of poisoning of cattle will occur in the future.

\section{ACKNOWLEDGEMENTS}

The authors acknowledge the expert in botanical garden Jože Bavcon $(\mathrm{PhD})$ for his help in the determination of poisoning plant redroot pigweed.

\section{REFERENCES}

[1] Šarić T. Atlas korova 100 najvažnijih vrsta korovskih biljaka u Jugoslaviji. $3^{\text {rd }}$ ed. Sarajevo, Svjetlost 1989; pp. 8-9.

[2] Egyed M, Miller A. Nitrate poisoning in cattle due to feeding on Amaranthus retroflexus. Refu Vet 1963; 20: 167-9.

[3] Stuart BP, Nicholson SS, Smith JB. Perirenal oedema and toxic nephrosis in cattle associated with ingestion of pigweed. J Am Vet Med Assoc 1975; 167(10): 949-50.

[4] Spearman G. Redroot pigweed toxicosis in cattle. Can Vet J 1989; 30: 255-6.

[5] Casteel SW, Johnson GC, Miller MA, et al. Amaranthus retroflexus (Redroot pigweed) poisoning in cattle. J Am Vet Med Assoc 1994; 204(7): 1068-70.

[6] Torres MB, Kommers GD, Dantas AF, de Barros CL. Redroot pigweed (Amaranthus retroflexus) poisoning of cattle in southern Brazil. Vet Hum Toxicol 1997; 39(2): 94-6.

[7] Kerr LA, Kelch WJ. Pigweed (Amaranthus retroflexus) toxicosis in cattle. Vet Hum Toxicol 1998; 40(4): 216-8.

[8] Gregorović V. Bolezni in zdravstveno varstvo prežvekovalcev; organske, presnovne in deficitarne bolezni, $4^{\text {th }}$ ed., Ljubljana, Univerza v Ljubljani, Veterinarska fakulteta 1992: pp. 633-4.

[9] Salyi G, Molnar T, Ratz F. Renal injury caused by feeding redroot pigweed (Amaranthus retroflexus) in swine. Case report. Magy Allator Lap 1996; 51(10): 603-6.

[10] Osweiler GD, Buck WB, Bicknell EJ. Production of perirenal oedema in swine with Amaranthus retroflexus. Am J Vet Res 1969; 148: 1525-31.

[11] Jeppesen QE. Bovine perirenal disease associated with pigweed. J Am Vet Med Assoc 1966; 149(1): 22. 
[12] Schamber GJ, Misek AR. Amaranthus retroflexus (Redroot pigweed): inability to cause renal toxicosis in rabbits. Am J Vet Res 1985; 46 (1): 266-7.

[13] Sebastian MM, Baskin SI, Czerwinski SE. Renal toxicity. In: Gupta RC, Ed. Veterinary toxicology, Basic and clinical principles. Amsterdam, Elsevier 2007; pp. 161-76.

[14] Radostits OM, Gay CC, Hinchcliff KW, Constable PD. Veterinary medicine. A textbook of the diseases of cattle, horses, sheep, pigs, and goats. $10^{\text {th }}$ ed. Edinburgh, Saunders Elsevier 2007; pp. 185561.
[15] Last RD, Hill JH, Theron G. An outbreak of perirenal oedema syndrome in cattle associated with ingestion of pigweed (Amaranthus hybridus). J S Afr Vet Assoc 2007; 78(3): 171-4.

[16] Galey FD. Disorders caused by toxicants. In Smith BP, Ed. Large animal internal medicine. $3^{\text {rd }}$ ed., St. Luis, Mosby 2002; 1614-37.

[17] Jones TO. Nitrate/nitrite poisoning in cattle. In Practice 1988: pp. 199-203.

[18] Stöber M. Nitrat- Nitritvergiftung. In: Dirksen G, Gründer HD, Stöber M, Eds. Innere Medizin und Chirurgie des Rindes. $5^{\text {th }}$ ed. Stuttgart, Parey 2006; pp. 235-9.

(C) Zadnik et al.; Licensee Bentham Open.

This is an open access article licensed under the terms of the Creative Commons Attribution Non-Commercial License (http://creativecommons.org/licenses/by$\mathrm{nc} / 3.0 /$ ) which permits unrestricted, non-commercial use, distribution and reproduction in any medium, provided the work is properly cited. 